Brit. J. vener. Dis. (1964), 40, 148.

\title{
OBITUARY
}

\section{JAMES JOHNSTON ABRAHAM, C.B.E., D.S.O., M.D., F.R.C.S. (1876-1963)}

Johnston Abraham might have been considered as the doyen of consultant venereologists, except that (following the tradition of the Honorary Staff of the London Lock Hospitals) he practised also as a general surgeon and more especially as a urologist. He died on August 9, 1963, after only a few days' illness, a week before his 87 th birthday. He was born in Coleraine, Co. Derry, the eldest son of William Abraham, and a direct descendant of Thomas Abraham, who was an officer in Cromwell's army. James Johnston Abraham (known widely as J.J.A.) also was descended through his mother from Scottish Covenanting stock who settled in Antrim at the time of the Plantation. Originally the family were Quakers, but during the latter half of the 19th century they became Methodists. Young James attended the Coleraine Grammar School and then passed on to Trinity College, Dublin in 1894, where he won prizes in English Literature, obtained his B.A. in 1898, and then became Gold Medallist in Natural Science. Although he went on and graduated M.B., B.Ch., B.A.O. in 1900, there was always the conflict in his mind between medicine and literature. While working at Steeven's Hospital he wrote his first novel The Night Nurse, which was banned by all hospital matrons except Guys'! Although he had great difficulty in getting it published, it was subsequently filmed in U.S.A., and in many European countries.

In 1901 he came to England in charge of his college crew at the Henley regatta and became house surgeon at the West London Hospital and also to Mr. McAdam Eccles.

J.J.A.'s subsequent career is well described in his own autobiography which he called $A$ Surgeon's Story. He once described, with a twinkle in his eye, how hard it had been to find a title for this book, for he found that all the more obvious titles had been used by people of whom he (for one) had never even heard. The years covered by this book coincided with marked developments in the study of venereal diseases. He was Registrar to the London Lock Hospitals and also was R.M.O. to the Women's Hospital, Harrow Road, and while there wrote his best seller $A$ Surgeon's Log, for which he gained the necessary material during a cruise as ship's doctor.

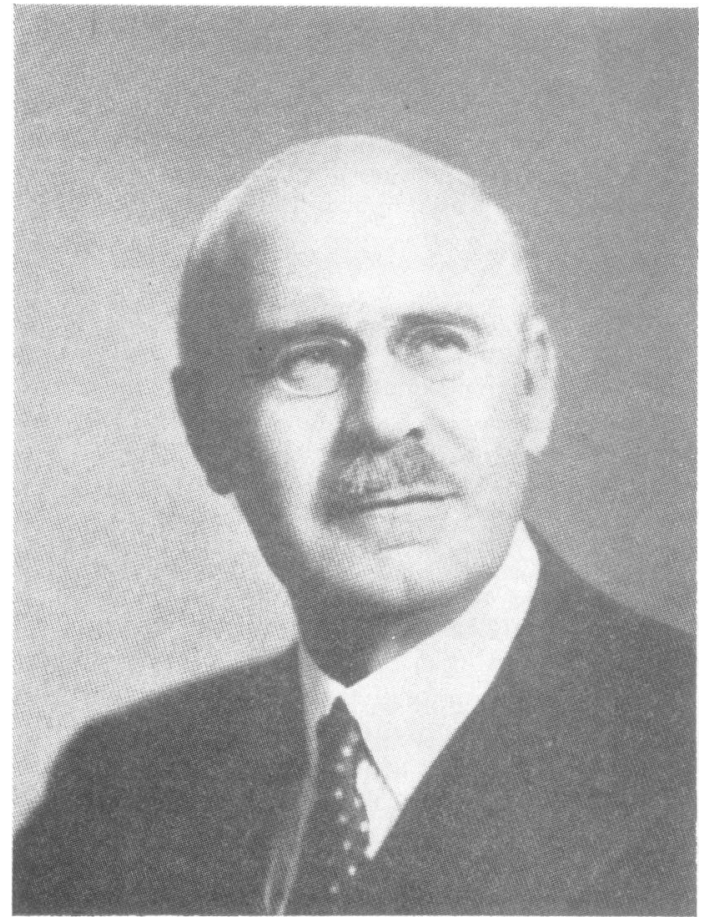

After the 1914-18 war, in which he distinguished himself first in the Serbian campaign, and then as A.D.G.M.S. Egypt and A.D.M.S. Palestine, he was, much to his surprise, appointed to the Honorary Staff of the London Lock Hospital at Dean Street. He won the D.S.O. after the capture of Jerusalem, and in 1919 was awarded the C.B.E.

Appointment to the Lock Hospital for Women followed in 1922 while his general surgery was practised at the Princess Beatrice Hospital, Kensington, and his private practice grew apace.

He married in 1920 Lillian Francis, whose father was a well-known specialist in the treatment of asthma and allied diseases, and who always maintained that if the blood Wassermann reaction had not been discovered he would never have met his future wife and ideal companion-as she was working in a laboratory at the time. 
While working intensively at his hospitals and in private, J.J.A. found time to indulge in his other great love, i.e. writing. Following Cronin's The Citadel, J.J.A. felt that some effort must be made to counteract, if possible, the cynical atmosphere that this novel had engendered. He therefore decided to write a series of stories in a lighter vein that would appeal to a wider public. For this he adopted the name James Harpole, derived from the first syllables of two of the medical streets, i.e. Harley and Wimpole. Many of these stories were heard on the radio, and one of them at least, The Surgeon's Heritage, was translated into ten European languages.

During the 1930s he was made a director of Heinemann's Medical Books Ltd., and in 1942 he became the managing director-which post he held until his death.

Mention must be made of the important Vicary Lecture which he gave at the Royal College of Surgeons in 1943, and the Lloyd Roberts Oration in 1948. He was a Trustee of the Hunterian Collection at the Royal College of Surgeons from 1954 and because of this was able to arrange for that body to take care of the pictures and other valuables of historical interest when the London Lock Hospital was compulsorily closed in 1952 by the Ministry of Health.

Johnston Abraham led the fight to save these over 200-year-old hospitals, but the combination of a valuable building site with heavy endowments, proved too tempting for bureaucracy and action comparable to that of Henry VIII in the dissolution of the monasteries, nearly broke J.J.A.'s heart. Anyone with any foresight realized that (human nature being what it is) it was only a question of time before the need for a centre for the adequate diagnosis and treatment of venereal and allied disorders would reappear. However, such arguments met with no support by the "powers that be" and the London Lock Hospitals died in 1952 after 207 years of service-as J.J.A. so graphically described in his autobiography.

His other interests were attending the meetings of the Savage Club, and the study of rare books and manuscripts of medical history. He was also a valued foundation member of the Irish Genealogical Research Society.

It seems astounding that one man could accomplish so much, but it would appear that this was due to an intense interest in people and in the subject under discussion. The role of consultant came naturally to him. He said on many occasions that he was never bored, and the writer, who had the privilege of serving as his house surgeon, his registrar, and, eventually, his colleague on the consultant staff, would heartily endorse this.

J.J.A. was a unique, though a very human, personality.
G.M.S.

\section{BOOK REVIEW}

World Health and History. By W. Hobson, M.D. 1963. Pp. 264, 49 illus. Wright, Bristol. (45s.).

Dr. Hobson was formerly professor of Social and Industrial Medicine at Sheffield and is now with the WHO Regional Office for Europe. He has studied disease and its control in many countries in both war and peace and is clearly concerned not only with present problems but also with the history and the future of preventive medicine. He writes interestingly about the hazards, both ancient and modern, to individual and community health against a global background, and provides historical detail not hitherto readily available. With such a comprehensive and ambitious field it is perhaps not surprising that the book contains a few minor errors but these do not detract from its interest and readability. 